\title{
Network analysis on nitrogen cycling in a coastal lagoon
}

\author{
E. Forès ${ }^{1}$, R. R. Christian ${ }^{2}$, F. A. Comín ${ }^{1}$, M. Menendez ${ }^{1}$ \\ ${ }^{1}$ Departament d'Ecologia, Facultat de Biologia, Universitat de Barcelona, Diagonal 645, E-08028 Barcelona, Spain \\ ${ }^{2}$ Department of Biology, East Carolina University, Greenville, North Carolina 27858, USA
}

\begin{abstract}
Network analysis was applied to nitrogen cycling data from 6 ecosystem components (phytoplankton, Potamogeton pectinatus, Ruppia cirrhosa, detritus plus heterotrophs, sediment, and dissolved inorganic nitrogen) in Tancada Lagoon (Ebro River delta, NE Spain) to ascertain (1) the relative importance of internal recycling versus external exchanges, (2) the main biogeochemical processes and (3) the fate of nitrogen imported to the lagoon. We compared cycling from 2 periods of the year: May-October, dominated by freshwater inputs, and November-April, dominated by seawater. Nitrogen recycling in the lagoon is equal to or more important than exchanges with other ecosystems, as indicated by the Finn Cycling Index $(\mathrm{FCl})$. FCI values are the percentage of total flow in the network which is associated with internal cycles and not with imports or exports. These internal cycles involve flows from a compartment that can be traced through 1 or more other compartments and back to the original. FCI values were $62 \%$ during the freshwater period and $52 \%$ during the seawater period. Nitrogen input to the lagoons was mainly as detritus plus heterotroph nitrogen $(0.81$ and $0.51 \mathrm{mmol} \mathrm{N}$ $\mathrm{m}^{-2} \mathrm{~d}^{-1}$ during the fresh- and seawater periods respectively). Most nitrogen export was as phytoplankton $\left(0.2 \mathrm{mmol} \mathrm{N} \mathrm{m} \mathrm{N}^{-2} \mathrm{~d}^{-1}\right.$ during both periods). Denitrification rates were comparable to other exports $\left(0.17\right.$ and $0.09 \mathrm{mmol} \mathrm{m} \mathrm{m}^{-2} \mathrm{~d}^{-1}$ during the fresh- and seawater periods respectively). Sediment played a key role in the internal recycling of nitrogen. A total of $80 \%$ of the phytoplankton nitrogen flow came indirectly from ammonium fluxes between sediment and water during the freshwater period, and $60 \%$ during the seawater period. Thus several differences were noted in the $N$ cycles between these 2 periods involving both the amount of recycling and the relative importance of different processes to the fate of nitrogen.
\end{abstract}

KEY WORDS: Network analysis · Nitrogen $\cdot$ Coastal lagoons

\section{INTRODUCTION}

Availability of nitrogen supply to the euphotic zones of aquatic ecosystems is important, particularly in coastal systems, because primary production is often limited by nitrogen (Ryther \& Dunstan 1971). Coastal lagoons in the Ebro River delta, NE Spain, are shallow systems where average water depth is between 35 and $48 \mathrm{~cm}$ (Comín 1984). Because of the shallow depth, macrophytes develop important communities, and nitrogen from the sediment may be used by both phytoplankton (after its flux from sediment to water) and rooted macrophytes. The source water for these lagoons changes from fresh in warmer months associated with rice cultivation to saline during other seasons (Comin 1984). Seitzinger et al. (1991) proposed that the release of inorganic nitrogen from sediments is dominated by denitrification in freshwater systems and by ammonium efflux in marine and estuarine systems. The difference in pattern results from differential competition between physical diffusion and nitrification/denitrification in the 2 systems. Therefore both seasonal salinity changes and macrophyte growth may be important in determining the exchanges of nitrogen between sediments and water in these coastal lagoons.

Elemental cycles have often been represented as multicompartmental models in which compartments are reservoirs of an element and fluxes between compartments are the transfers and transformations of the element (Shugart \& O'Neill 1979). A group of analyses in which algorithms are used to evaluate the model's structure is collectively called 'network analysis' 
(Ulanowicz 1986). The analyses are designed to evaluate the qualitative (connections among compartments) and quantitative (the amounts of each flux) structure of the system. For network analysis only static models are required involving time-averaged standing stocks and flows. There is no need to hypothesize equation forms for dynamic simulation (Mann et al. 1989). Although static conditions are used, a steady state is not necessarily required for all of the algorithms needed in the analysis. As a result of network analysis, new perspectives can be gained about the model system and, inferentially, about the natural elemental cycle. Among the results that can be obtained are the following: (1) the ability to evaluate the dependencies of one compartment's flow upon all other compartments whether or not a direct connection between compartments exists; (2) the probable fate of atoms imported into the system; (3) the distribution and importance of internal positive feedback loops (called cycles); and (4) the relative importance of recycling to import. Thus, network analysis provides powerful tools for the interpretation of nutrient cycling (Ulanowicz 1986, Wulff \& Ulanowicz 1989).

We have constructed 2 models of the nitrogen cycle for Tancada Lagoon (Ebro River delta). The first model includes data obtained during the freshwater period. The second one includes data obtained during the seawater period. Both models were subjected to ecological network analysis to evaluate (1) the fate of nitrogen coming from ricefields during the freshwater period and from the sea during the seawater period, (2) the relative importance of ammonium diffusion versus denitrification in both periods, and (3) the importance of internal recycling.

\section{MATERIAL AND METHODS}

Study site. Tancada Lagoon is located in the Ebro River delta, NE Spain (Fig. 1). This lagoon $\left(1.8 \mathrm{~km}^{2}\right.$. $76 \mathrm{~cm}$ maximum depth) is surrounded by ricefields except on its east side where a small marsh area (dominated by Arthrocnema sp.) separates the lagoon and the sea.

Freshwater comes from the ricefields during the whole rice cultivation period (May to October). During these months rooted macrophytes Ruppia cirrhosa and Potamogeton pectinatus develop maximum biomass. Conductivity values are less than $10 \mathrm{mS} \mathrm{cm}^{-1}$ (Comin 1984, Comín et al. 1987).

Ricefields are harvested at the end of the cultivation period, and canals bringing freshwater to the lagoons are closed from November to April. Conductivity increases as marine water comes into the lagoon through canals that connect the coastal lagoon with the

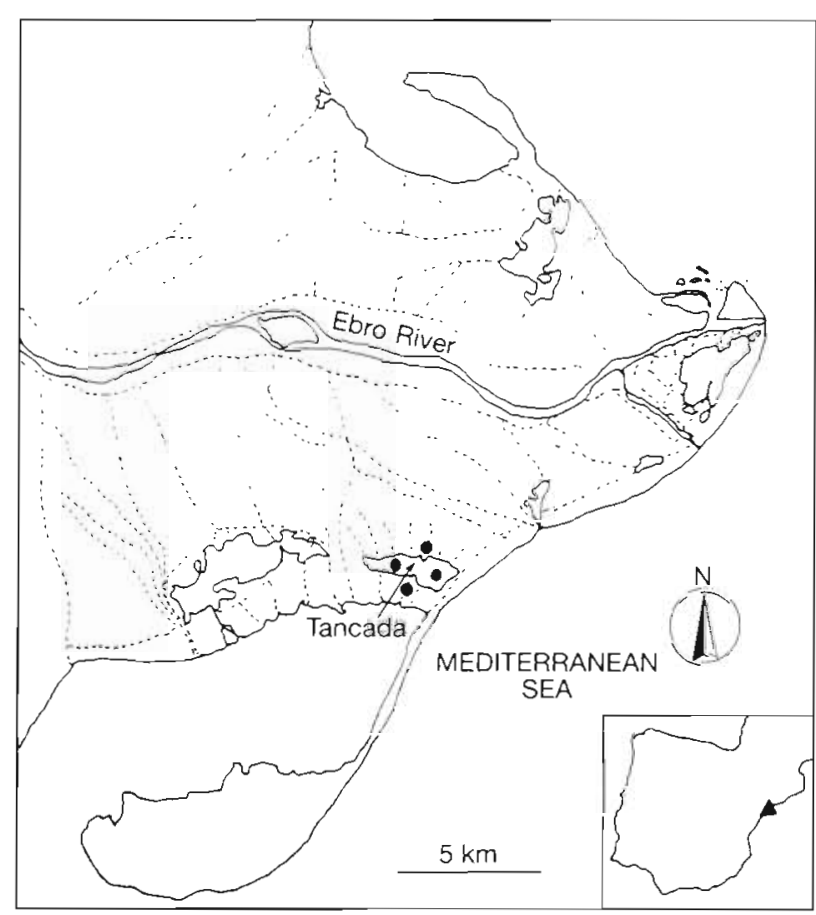

Fig. 1. Ebro River delta, NE Spain, showing location of the studied lagoon

bay. Maximum salinity values are observed in April $\left(40 \mathrm{mS} \mathrm{cm}^{-1}\right)$. At the end of September macrophytes lose their leaves, which then decompose in the water column and on the sediment (Menendez et al. 1989). A sampling station was located in each of 2 basins of the lagoon and in the main inflow and outflow canals. Further details on the study area and methods are described in Comín (1984) and Menendez \& Comín (1989).

Model construction. We developed multicompartmental models representing various standing stocks of nitrogen with interactions or fluxes between compartments and with outside the system (inputs, outputs and dissipations resulting from respiration, i.e. denitrification). The units are $\mathrm{mmol} \mathrm{m}^{-2}$ for standard stocks and mmol $\mathrm{m}^{-2} \mathrm{~d}^{-1}$ for fluxes (Fig. 2).

Six compartments were considered in our models, constructed with data corresponding to the freshwater period $(210 \mathrm{~d})$ and seawater period $(150 \mathrm{~d})$ : phytoplankton (PHY), Ruppia cirrhosa (RUP), Potamogeton pectinatus (POT), detritus plus aquatic heterotrophs (DET), sediment (SED) and dissolved inorganic nitrogen (DIN). Measured external inputs and outputs were made for PHY, DET and DIN. Standing stocks were measured directly (Table 1) with the exception of nitrogen in PHY, which was estimated from chlorophyll measurements and conversions to nitrogen (Christian et al. 1992). Nitrogen DET was determined as particu- 


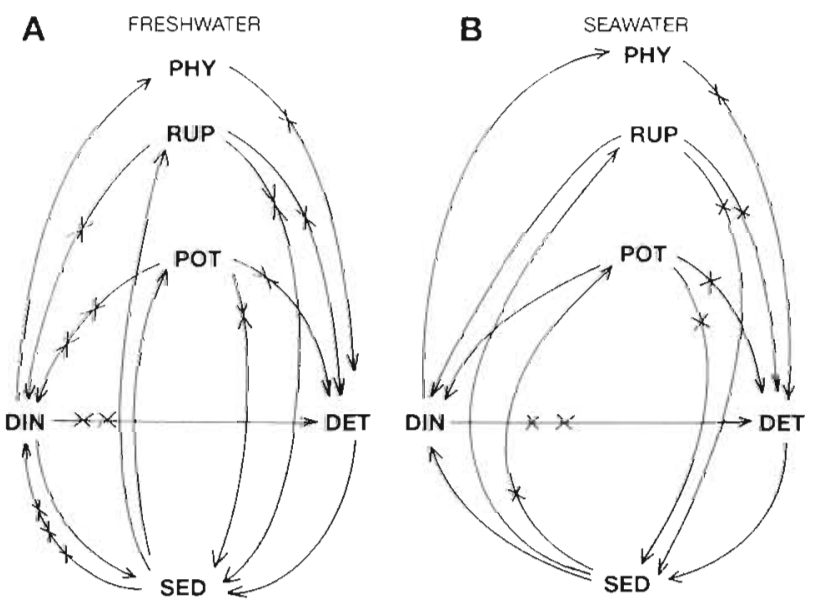

Fig. 2. Pathways of internal biogeochemical cycling of nitrogen in Tancada Lagoon. (A) Cycle structuring for freshwater; (B) cycle structuring for seawater. An ' $X$ ' on an arrow refers to a weak arc. PHY: phytoplankton; RUP: Ruppia cirrhosa; POT: Potamogeton pectinatus; DET detritus plus heterotrophs; SED: sediment; DIN: dissolved inorganic nitrogen

late nitrogen minus phytoplankton nitrogen. Standing stocks were converted to imports and exports using water flow data measured with a flow meter. We measured denitrification rates by applying acetylene blockage (Tiedje et al. 1989).

We calculated 14 and 13 internal interactions for the freshwater and seawater period models respectively. Eight of them (macrophyte decomposition and DIN release and uptake by sediment) were directly measured or calculated from laboratory experiments. Flux of nitrogen from sediment to water was measured directly through core incubations in situ. Ammonium, nitrates and nitrites were analyzed at the begining and after $4 \mathrm{~h}$. The observed results compared favorably to the results obtained by Vidal (1990) using a similar method in the bay close to the coastal lagoon with similar granulometric characteristics. Ruppia cirrhosa and Potamogeton pectinatus decomposition rates were estimated using the litter bag method (Menendez et al. 1989). Also data on invertebrate consumption of macrophytes were used to calculate the flow from macrophytes (RUP and POT) to DET. Macrophyte nitrogen uptake rates were calculated from increases in standing stock (Menendez \& Comín 1989) providing a minimum estimate. The relationships between DIN uptake by PHY and by DET were calculated from primary productivity data (Comín 1984) according to Christian et al. (1992). Phytoplankton to detritus and detritus sedimentation were the only interactions calculated through mass balance (Table 2). Neither steady state nor mass balance were achieved; however, the analyses we employed did not require them.

We used ecological network analysis to interpret the nature of nitrogen cycling in our models. We consider 2 analyses here: structure analysis and biogeochemical cycle analysis. We used the computer package NETWORK 4 (R. E. Ulanowicz, University of Maryland, Center for Environmental and Estuarine Studies, Chesapeake Biological Laboratory, Solomons, MD 20688-0038, USA). Details of analyses are described in depth by Ulanowicz (1986) and Kay et al. (1989).

Structure analysis is an outgrowth of input-output analysis first developed for economic systems. It involves a series of matrix algebra manipulations, the results of which are matrices and vectors designed to quantify both direct and indirect effects of imports and interactions. The total dependency matrix is used to evaluate the fraction of a compartment's total input that resided at some point in another compartment. The connection may be either direct or indirect. This matrix is normalized to the throughput of compartments. The throughput of a compartment is the total

Table 1. Standing stocks of the measured variables in Tancada Lagoon

\begin{tabular}{|c|c|c|c|c|c|c|c|}
\hline \multirow[t]{2}{*}{ Month } & \multicolumn{2}{|c|}{ Ruppia cirrhosa } & \multicolumn{2}{|c|}{ Potamogeton pectinatus } & \multirow{2}{*}{$\begin{array}{c}\mathrm{Chl} \mathrm{a} \\
\left(\mathrm{mg} \mathrm{m}^{-3}\right)\end{array}$} & \multirow{2}{*}{$\begin{array}{c}\text { Total particulate } \\
\text { nitrogen } \\
(\mu \text { mol l ') }\end{array}$} & \multirow{2}{*}{$\begin{array}{c}\text { DIN } \\
\left(\mu \mathrm{g}-\mathrm{at} . \mathrm{I}^{-1}\right)\end{array}$} \\
\hline & $\begin{array}{c}\text { Biomass } \\
\text { (g AFDW m }{ }^{-2} \text { ) }\end{array}$ & $\% N$ & $\begin{array}{c}\text { Biomass } \\
\text { (g AFDW } \mathrm{m}^{-2} \text { ) }\end{array}$ & $\% \mathrm{~N}$ & & & \\
\hline May & 96.8 & 1.45 & 48.4 & 1.29 & 1.32 & 20.71 & 3.7 \\
\hline Jun & 247.7 & 2.19 & 81.5 & 1.61 & 6.48 & 10.71 & 10.55 \\
\hline Jul & 241.7 & 2.23 & 174.1 & 1.44 & 7.63 & 14.64 & 36.53 \\
\hline Aug & 217.2 & 2.13 & 225.5 & 1.14 & 4.05 & 8.92 & 164.84 \\
\hline Sep & 363.8 & 1.87 & 162.4 & 1.00 & 6.21 & 9.63 & 7.62 \\
\hline Oct & 212.8 & 1.62 & 246.2 & 1.14 & 38.31 & 15.71 & 11.02 \\
\hline Nov & 383.9 & 1.79 & 203.1 & 1.12 & 13.26 & 19.64 & 11.63 \\
\hline Dec & 320.2 & 1.67 & 505.6 & 0.91 & 3.22 & - & 4.97 \\
\hline Jan & - & - & - & - & 20.86 & 24.64 & 8.51 \\
\hline Feb & 347.0 & 1.89 & - & - & 8.63 & 36.90 & 3.89 \\
\hline Mar & 285.3 & 1.80 & 144.0 & 1.06 & 7.22 & 21.06 & 0.89 \\
\hline Apr & 209.8 & 1.67 & 287.2 & 1.21 & 7.13 & 24.40 & 1.74 \\
\hline
\end{tabular}


Table 2. Information for model of nitrogen cycle at the studied coastal lagoon at different periods. Details of measured variables are given in text

\begin{tabular}{|c|c|c|c|}
\hline Variable & $\begin{array}{l}\text { Freshwater } \\
\left(\mathrm{mmol} \mathrm{N} \mathrm{m}{ }^{-2} \text { ) }\right.\end{array}$ & $\begin{array}{c}\text { Seawater } \\
\left(\mathrm{mmol} \mathrm{N} \mathrm{m}^{-2}\right)\end{array}$ & Source \\
\hline Phytoplankton & 3.68 & 3.68 & Comin (1984) \\
\hline Ruppia cirrhosa & 210.37 & 252.90 & Menendez (1990), Menendez \& Comín (1989) \\
\hline Potamogeton pectinatus & 50.00 & 58.10 & Menendez (1990), Menendez \& Comín (1989) \\
\hline Heterotrophs + detritus & 10.60 & 23.07 & Comin (1984), Comín et al. (1990) \\
\hline Sediment & 1687.80 & 1867.80 & Gonzalez et al. (in press) \\
\hline DIN & 16.20 & 3.48 & Comín (1984), Comín et al. (1990) \\
\hline \multicolumn{4}{|l|}{ Imports (mmol $\mathrm{N} \mathrm{m}^{-2} \mathrm{~d}^{-1}$ ) } \\
\hline Phytoplankon & 0.0840 & 0.0043 & Comín (1984) \\
\hline Heterotrophs + detritus & 0.8110 & 0.5070 & Comin (1984) \\
\hline $\mathrm{DIN}$ & 0.0990 & 0.1570 & Comín (1984), Comín et al. (1990) \\
\hline \multicolumn{4}{|l|}{ Exports (mmol $\mathrm{N} \mathrm{m}^{-2} \mathrm{~d}^{-1}$ ) } \\
\hline Phytoplankon & 0.240 & 0.224 & Comín (1984) \\
\hline DIN & 0.073 & 0.020 & Comín (1984), Comín et al. (1990) \\
\hline \multicolumn{4}{|l|}{ Dissipations (mmol $\mathrm{N} \mathrm{m}^{-2} \mathrm{~d}^{-1}$ ) } \\
\hline Denitrification & 0.178 & 0.089 & Astorga (pers. comm.) \\
\hline \multicolumn{4}{|l|}{ Interactions (mmol $\mathrm{N} \mathrm{m}^{-2} \mathrm{~d}^{-1}$ ) } \\
\hline Phytoplankton - detritus & 1.13 & 0.30 & Mass balance \\
\hline Ruppia - detritus & 2.42 & 2.56 & Menendez \& Comín (1990), Menendez et al. (1989) \\
\hline Ruppia-sediment & 0.38 & 0.23 & Menendez (1990) \\
\hline Ruppia-DIN & 1.02 & 0.53 & Menendez (1990) \\
\hline Potamogeton-detritus & 0.43 & 0.23 & Menendez \& Comín (1990), Menendez et al. (1989) \\
\hline Potamogeton - sediment & 0.05 & 0.06 & Menendez $(1990)$ \\
\hline Potamogeton - DIN & 0.20 & 0.43 & Menendez (1990) \\
\hline Detritus - sediment & 4.99 & 3.65 & Mass balance \\
\hline Ruppia - N uptake & 5.00 & 1.67 & Menendez (1990) \\
\hline Potamogeton - N uptake & 0.84 & 0.63 & Menendez (1990) \\
\hline Sediment - DIN & 5.13 & 2.40 & Vidal (1990), Forès (unpubl. data) \\
\hline Phytoplankton - N uptake & 1.14 & 0.31 & Comin (1984) \\
\hline Heterotrophs - N uptake & 0.28 & 0.08 & Comin (1984) \\
\hline Sediment - DIN uptake & 0.003 & 0 & Vidal (1990), Forès (unpubl. data) \\
\hline
\end{tabular}

amount of flow passing through it. Also, the contribution of each import from outside the system to flows is evaluated through a series of vectors and matrices. Each import is considered separately. A coefficient in each vector and matrix represents the number of times an atom of imported nitrogen passes along a particular flow path between entering and leaving the system.

Biogeochemical cycle analysis employs graph theory to evaluate the characteristics of internal cycles or positive feedback loops within the system. An arc is a flow between 2 compartments. A series of arcs which in combination pass material from one compartment, through 1 or more other compartments, and returns material to the original one, is called a cycle. The arc within a cycle which has the smallest flow is the weak arc, and a group of cycles sharing the same weak arc is a nexus. One may infer that the weak arc is potentially the controlling flow within a cycle and that cycles in a nexus have a common control. As cycles may have different lengths and quantities of flow, a system is characterized by not only the number of cycles but also the distribution of flow according to length. Lastly, as the total flow associated with these cycles represents cycled throughput it can be compared to flows into or out of the system or to total flow (total system throughput). This cycled throughput as a percentage of total system throughput is called the Finn Cycling Index (FCI; Finn 1980).

\section{RESULTS}

From May to October dissolved inorganic nitrogen (DIN) comes to Tancada Lagoon through canals that transport freshwater from ricefields, and from November to April through canals that connect this lagoon with the Mediterranean Sea. Imports of DIN by source during both periods are summarized in Table 2. Freshwater imports are higher than seawater imports $(0.99$ and $0.67 \mathrm{mmol}$ total nitrogen $\mathrm{m}^{-2} \mathrm{~d}^{-1}$ respectively). Structure analysis was used to assess the fate of nitrogen coming into the lagoon from external systems. 
Table 3. Fates of nitrogen from freshwater and seawater with respect to phytoplankton, heterotrophs plus detrtitus and denitrification

\begin{tabular}{|lcc|}
\hline & Freshwater & Seawater \\
\hline $\begin{array}{l}\text { Rate of input } \\
\text { (mmol } \mathrm{N} \mathrm{m}^{-2} \mathrm{~d}^{-1} \text { ) }\end{array}$ & 0.99 & 0.67 \\
$\begin{array}{l}\text { Atoms of } \mathrm{N} \text { processed } \\
\text { equivalent to 1 atom input: } \\
\text { to phytoplankton }\end{array}$ & & \\
$\begin{array}{l}\text { to heterotrophs + detritus } \\
\text { to denitrification }\end{array}$ & 0.208 & 0.094 \\
& 0.002 & 0.024 \\
\hline
\end{tabular}

During the freshwater period $20.8 \%$ of DIN import is involved in the flow from DIN to the phytoplankton compartment, and $5.5 \%$ is associated with the uptake of DIN by heterotrophs. Denitrification releases an equivalent to $0.2 \%$ of imported DIN (Table 3). During the seawater period the DIN import to phytoplankton decreases to $9.4 \%$. Also DIN import to heterotrophs decreases to $2.4 \%$ of DIN import. During this period $0.5 \%$ of DIN input is released by denitrification.

If we compare nitrogen dissipation by denitrification with nitrogen release from sediment to water, we observe that both values are higher during the freshwater period compared to the seawater period, but the ratio of DIN release from sediment to denitrification is 28 and 27 in each period (Table 1). The DIN compartment is highly dependent upon sediment nitrogen in both periods. $98.5 \%$ of DIN throughput had been through the SED compartment during the freshwater period and $84.1 \%$ during the seawater period (Table 4).

Table 4. Total dependency coefficient matrices indicating the percentage of flow through a recipient compartment (columns) that once resided in a donor compartment (rows). Relationships can be direct or indirect

\begin{tabular}{|lrrrrrr|}
\hline \multirow{2}{*}{ Donor } & \multicolumn{7}{c}{ Recipient } \\
& PHY & RUP & POT & DET & SED & DIN \\
\hline Freshwater period & & & & & & \\
PHY & 11.9 & 14.6 & 14.6 & 31.3 & 14.6 & 14.3 \\
RUP & 34.1 & 30.5 & 30.5 & 60.2 & 30.5 & 41.0 \\
POT & 8.1 & 7.1 & 7.1 & 14.2 & 7.1 & 9.8 \\
DET & 38.2 & 46.6 & 46.6 & 37.2 & 46.6 & 45.9 \\
SED & 81.9 & 100.0 & 100.0 & 79.9 & 39.6 & 98.5 \\
DIN & 83.2 & 15.2 & 15.2 & 32.6 & 15.2 & 15.0 \\
Seawater period & & & & & & \\
PHY & 4.90 & 4.92 & 6.73 & 12.1 & 9.78 & 8.23 \\
RUP & 3.84 & 3.28 & 44.90 & 76.7 & 65.20 & 64.90 \\
POT & 12.50 & 5.63 & 7.70 & 12.4 & 11.20 & 21.20 \\
DET & 40.10 & 40.10 & 55.40 & 36.6 & 80.50 & 67.80 \\
SED & 49.80 & 50.13 & 68.80 & 45.4 & 38.70 & 84.10 \\
DIN & 59.20 & 4.13 & 5.65 & 10.2 & 8.21 & 6.91 \\
\hline
\end{tabular}

Phytoplankton was highly dependent upon sediment nitrogen, mainly during the freshwater period when $81.9 \%$ of its nitrogen throughput had been through the SED compartment with DIN as intermediate. During the seawater period phytoplankton's dependence on sediment decreased to $50 \%$. Dependency of phytoplankton throughput on DIN in water was also higher during the freshwater period $183.2 \%$ of its total throughput) than during the seawater period $(60 \%$ of its total throughput). The remainder of phytoplankton throughput was associated with importation of phytoplankton and imbalance in inputs and exports.

Sediment nitrogen depended less on aquatic compartments (DIN, PHY or DET) than vice versa. Maximum dependence was observed with DET (46.6 to $80.5 \%$ of sediment nitrogen throughput had been in the DET compartment). The degree of sediment recycling, obtained from the total dependency matrix (Table 4) at the cell where SED is both donor (row) and recipient (column) was about $40 \%$, obtained in both the freshwater and the seawater period. This is the percentage of sediment throughput that had previously been in the SED compartment, left and returned.

All $\mathrm{N}$ for the 2 macrophytes came directly from sediments. However non-steady-state conditions affected dependencies less than $100 \%$ in the seawater period (Table 4). During the seawater period nitrogen outputs from decomposition exceeded inputs, and compartmental throughputs were calculated as inputs plus $N$ is equal to the amount of decrease in standing stock. These imbalances between throughput and input caused dependency of their throughputs on sediment of about $50.1 \%$ by Ruppia cirrhosa and $68.8 \%$ by Potamogeton pectinatus.

Both macrophytes had an indirect dependency of about $50 \%$ on DET. DET throughput depended directly on the 2 macrophytes and phytoplankton. The dependence on Ruppia cirrhosa was higher than that on Potamogeton pectinatus or phytoplankton. Dependency by DET on $R$. cirrhosa was higher during the seawater period $(76.7 \%)$ than during the freshwater period $(60.2 \%)$. This is the reverse of the pattern for dependence on phytoplankton. Dependence on P. pectinatus was similar for both periods.

The structure of biogeochemical cycles differed between periods of the year. The number of cycles was greatest during the freshwater period (13 cycles). Once DIN to SED flow disappeared in the seawater period, the number of cycles decreased to 10 
(Fig. 2). During the freshwater period DIN was involved in 8 of the 13 weak arcs observed. Two of the 3 flows into DIN are weak arcs, both from macrophytes. Two of the 3 DIN uptakes are weak arcs (to SED and to DET). All inputs to DET are weak arcs during the seawater period.

\section{DISCUSSION}

We constructed the 2 models or networks of nitrogen cycling within the Tancada Lagoon as a way of collating data from several studies of this system. Network analysis allowed us to evaluate these collated data in novel ways. We were able to trace nitrogen along paths within the model, examine indirect relationships and compute a system level index of the amount of recycling (Finn 1980). Extrapolation of our results to Tancada Lagoon depends on how well the model translates salient features of reality. Our choice of compartments and flows (i.e. model structure) was designed to maximize the potential that extant data could be used to estimate needed values. Thus compartments, such as 'detritus' which also contains aquatic heterotrophs and 'sediment' which also contains all benthos, are highly aggregated. We rejected a food-web approach to modelling as we assumed that trophic structure of higher-order consumers contributes increasingly small explicit flows in biogeochemical cycling (Lindeman 1942). Also, we would have had to be more speculative with constructing a more elaborate food web. If consumers are primarily responsible for mineralization and smaller consumers are most responsible, our measurements and subsequent model values should embody the quantitatively important processes.

The primary producer compartments were divided to represent the 2 major macrophytes, which have different seasonal dynamics, and phytoplankton, which derive their nitrogen from DIN rather than from sediment and have a more rapid turnover We had considerable information on these compartments which are obviously the most important in the immobilization of nitrogen. Thus with our model we focused on these organisms and their potential to control nitrogen cycling.

The structure of a model influences the results of the network analysis. Each individual analysis is impacted in its own way. Aggregation of compartments which act in parallel to each other does not alter summed throughput (Ulanowicz \& Kemp 1979). Aggregating compartments connected in series reduces total system throughput. For a food web the magnitude of this reduction is to a large extent limited by the number of trophic levels. Thus, by aggregating the food web we have decreased this quantity relative to a more complex web. Aggregations will also have an influence on the number of cycles and their length. These issues must be recognized in making inferences about the natural system. Further, differences in model structure can confound comparisons with other ecosystem models, but the 2 models given here are consistent with each other and consistent in structure with others we have analyzed (Forès \& Christian 1993, Christian et al. in press). Throughput-based analysis of dependence, fate and cycling is generally less sensitive to aggregation than analyses that involve the designation of cycles. We place more emphasis on general patterns elucidated by network analyses and relative range of quantities than on claiming specific values for the natural ecosystem.

We found a high dependence on internal nitrogen recycling for both planktonic and benthic primary producers in Tancada Lagoon. This result is in agreement with those obtained by different authors (Nixon 1981a, Nowicki \& Nixon 1985, Pilson 1985, Christian et al. 1992) on the relative importance of internal nitrogen recycling to outside sources. Inputs of nitrogen are higher from May to October, the freshwater phase, when water enters primarily from ricefield drainage canals. During this period the main source of external nitrogen is in particulate form. Particulate nitrogen loading reflects both release of nitrogen from ricefields and subsequent metabolism in drainage canals (Forès 1992). From November to April, the seawater period, dissolved inorganic nitrogen increases its relative importance as nitrogen input. Phytoplankton depend directly on dissolved inorganic nitrogen, but a large quantity of phytoplankton nitrogen comes indirectly from ammonium flux between sediment and water. Sediment contributes about $80 \%$ of the phytoplankton nitrogen throughput during the freshwater period and $50 \%$ during the seawater period. Also nitrogen mineralization coming from decomposition of Ruppia cirrhosa and Potamogeton pectinatus at the end of the growing season (Menendez et al. 1989) can be an important source of dissolved inorganic nitrogen used by planktonic primary producers during late autumm and winter, as the observed dependency clearly indicates. Nutrient sources for rooted macrophytes are mainly sediment (Carignan \& Kalff 1980, Carignan 1985), but again we observe an important indirect dependence on internal recycling, since half of macrophyte nitrogen throughput comes from detritus, $R$. cirrhosa is the main source of detritus in Tancada Lagoon: $60 \%$ of DET throughput in the freshwater period and $77 \%$ in the seawater period comes from $R$. cirrhosa. Only $14 \%$ and $31 \%$ of DET nitrogen throughput in the freshwater period and $12 \%$ and $12 \%$ in the seawater period comes from $P$ pectinatus and phytoplankton 
respectively. So $R$. cirrhosa plays an important role in the internal recycling of nitrogen in Tancada Lagoon, as we expected from its higher biomass production and decomposition rates compared to $P$. pectinatus (Menendez 1990).

In sediments with oxidized surface layers, the percentage of mineralized nitrogen that is nitrified/ denitrified, compared with that released as ammonium, appears to be affected by the presence of salts (Gardner et al. 1991). Conductivity is low in Tancada Lagoon during summer and high in winter according to the different origins of water in both periods (Comin 1984, Comín et al. 1987). But ammonium flux from sediment to water is considerably higher than denitrification in both the seawater and freshwater periods This result is not in agreement with those obtained by Seitzinger (1988) and Gardner et al. (1991) in their comparisons of estuarine and freshwater systems. It has been proposed that a larger percentage of ammonium produced during the mineralization of organic nitrogen in freshwater sediment is lost from the ecosystem as $\mathrm{N}_{2}$ as a result of more efficient nitrification, and subsequent denitrification, compared to marine sediments (Gardner et al. 1987, Seitzinger 1988). Low denitrification during the freshwater period compared to the expected results can result from high levels of sulfate in the sediments and pore water from marine underground water input. Sulfate content of sediments and sulfate reduction that can inhibit nitrification/ denitrification processes during summer need further research to explain the results obtained. The fact that Tancada Lagoon alternates between marine and freshwater imports may explain this discrepancy with systems having consistent salinity regimes.

Coastal lagoons in the Ebro River delta may be qualified as eutrophic systems, considering the large quantity of dissolved nutrients observed (Comín 1984, Comin et al. 1987). It has been postulated that systems that are stressed by high nutrient loads have high FCIs and short biogeochemical cycles (Mann et al. 1989, Wulff \& Ulanowicz 1989). FCIs of $62 \%$ in the freshwater period and $52 \%$ in the seawater period indicate that at least $50 \%$ of the throughput of nitrogen within the lagoon is associated with internal cycling. These FCI values are within the range of those for nitrogen networks of other shallow eutrophic systems we have studied (Christian et al. 1992, Forès \& Christian 1993, Christian et al. in press). The longest cycles were of 5 arcs length, and only 3 of a total of 23 cycles found were that long. During the freshwater period we found 2 cycles of 5 arcs length, whereas in the seawater period we found only 1 . The significance of these patterns, however, cannot be ascertained until more comparable networks have been analyzed.

The Tancada Lagoon undergoes major changes between the 2 periods considered. Water source changes, temperature and resultant metabolic rates change, and the life history states of the macrophytes change. The nitrogen cycles of the 2 periods are different reflecting these changes. Internal cycling (FCI) decreases in the seawater period relative to the freshwater period, and the importance of processes involving DIN as the weak arc decreases. Although the absolute fluxes into and out of DIN generally decrease in the seawater period, the fluxes become larger relative to others involved in cycling. Flows of nitrogen from sediment to water and macrophytes are not weak arcs during the freshwater (growing) period, but these flows are less or below detection in winter. We infer that in the freshwater period nitrogen cycling and availability to primary producers are largely limited by the production of DIN. During the seawater period, when a large quantity of nitrogen in macrophytes comes from detritus, all the inputs to these compartments are weak arcs. This result agrees with the hypothesis that decomposition of macrophytes controls nitrogen cycling in coastal marine ecosystems dominated by rooted vegetation (Nixon 1981b).

Acknowledgements. This work was supported by EEC Environmental Protection Programme (EV4V-0132-E-TT) and CICYT-Spain (PAC84-16-CO2-O2).

\section{LITERATURE CITED}

Carignan, R. (1985). Nutrient dynamics in a littoral sediment. colonized by the submersed macrophyte Myriophyllum spicatum. Can. J. Fish. Aquat. Sci. 42: 1303-1311

Carignan, R., Kalff, J. (1980). Phosphorus sources for aquatic weed: water or sediments? Science 207: 987-989

Christian, R. R., Boyer, J. N., Stanley, D. W., Rizzo, W. M. (1992). Network analysis of nitrogen cycling in an estuary. In: Hurst, C. (ed.) Modelling the metabolic and physiologic activities of microorganisms. Wiley, New York

Christian, R. R., Forès, E., Comín, F. A., Viaroli, P., Ferrari, I. (in press). Comparative network analysis of nitrogen cycling in several eutrophic coastal ecosystems. Proc. 6th int. Symp. Microbial Ecology, Barcelona, Spain, 6-11 September 1993

Comín, F. A. (1984). Características físicas y químicas y fitoplancton de las lagunas costeras Encañizada, Tancada y Buda (Delta del Ebro). Oecol. aquat. (Barcelona) 7: 79-162 (in Spanish; English abstract)

Comín, F. A., Menendez, M., Forès, E. (1987). Salinidad y nutrientes en las lagunas costeras del Delta del Ebro. Limnetica 3: 1-8

Comín, F. A., Menendez, M., Lucena, J. R. (1990). Proposals for macrophyte restauration in eutrophic coastal lagoons. Hydrobiologia 200/201: 427-436

Finn, J. T (1980). Flow analysis of models of the Hubbard Brook ecosystem. Ecology 61: 562-571

Forès, E. (1992). Nutrient loading and drainage response in a ricefield system. Hydrobiologia 230: 193-200

Forès, E., Christian, R. R. (1993). Network analysis on nitro- 
gen cycling in temperate wetland ricefields. Oikos 67 : 299-308

Gardner, W. S., Nalepa, T. F., Malczyk, J. M. (1987). Nitrogen mineralization and denitrification in Lake Michigan sediments. Limnol. Oceanogr. 32: 1226-1238

Gardner, W. S., Seitzinger, S. P., Malczyk, J. M. (1991). The effects of sea salts on the forms of nitrogen released from estuarine and freshwater sediments: does ion pairing affect ammonium flux. Estuaries 14(2): 157-166

Gonzalez, S., Forès, E., Comín, F. A. (in press). Característiques físiques i quimiques del sediment de la llacuna de la Tancada (Delta de l'Ebre, Tarragona). Efecte de la presència de macròfits. Bull. Inst. Cat. His. Nat. (in Catalani English abstract)

Kay, J. J., Graham, L. A., Ulanowicz, R. E. (1989). A detailed guide to network analysis. In: Mann, K. H., Field, J. G., Wulff, F. (eds.) Network analysis in marine ecology: methods and applications. Springer-Verlag, Berlin, p. 15-16

Lindeman, R. L. (1942). The trophic dynamic aspect of ecology. Ecology 23: 399-418

Mann, K. H., Field, J. G., Wulff, F. (1989). Network analysis in marine ecology: an assessment. In: Mann, K. H., Field, J. G., Wulff, F. (eds.) Network analysis in marine ecology: methods and applications. Springer-Verlag, Berlin, p. $259-282$

Menendez, M. (1990). Ecologia de los macrofitos enraizados sumergidos en la laguna de la Tancada (Delta del Ebro, N.E. España). Ph.D. thesis, Universidad de Barcelona

Menendez, M., Comín, F. A. (1989). Seasonal patterns of biomass variation of Ruppia cirrhosa (Petagna) Grande and Potamogeton pectinatus $L$. in a coastal lagoon. Scientia mar. 53(2-3): $633-638$

Menendez, M., Comín, F. A. (1990). Consumption of macrophytes by invertebrates in Tancada Lagoon (NE Spain). Scientia mar. 54(2): 139-144

Menendez, M., Forès, E., Comín, F. A. (1989). Ruppia cirrhosa decomposition in a coastal temperate lagoon as affected by macroinvertebrates. Arch. Hydrobiol. 117(1): 39-48

Nixon, S. W. (1981a). Remineralization and nutrient cycling in coastal marine ecosystems. In: Neilson, B. J., Cronin, L. E. (eds.) Estuaries and nutrients. Humana Press, Clifton, NJ,

This article was submitted to the editor p. $111-138$

Nixon, S. W. (1981b). Freshwater inputs and estuarine productivity. In: Cross, R. D., Williams, D. L. (eds). Proc. Natl Symp. Freshwater Inflow to Estuaries, Vol. 1. FWS/OBS$81 / 04$, U.S. Fish and Wildlife Service, Office of Biological Services, p. 31-57

Nowicki, B. L., Nixon, S. W. (1985). Benthic nutrient remineralization in a coastal lagoon ecosystem. Estuaries 8: $182-190$

Pilson, M. E. Q. (1985). Annual cycles of nutrients and chlorophyll in Narragansett Bay, Rhode Island. J. mar. Res. 43: 849-873

Ryther, J. H., Dunstan, W. M. (1971). Nitrogen, phosphorus and eutrophication in the coastal marine environment. Science 171: 1008-1013

Seitzinger, S. P. (1988). Denitrification in freshwater and coastal marine ecosystems: ecological and geochemical significance. Limnol. Oceanogr. 33: 73-83

Seitzinger, S. P., Gardner, W. S., Spratt, A. K. (1991). The effect of salínity on ammonium sorption in aquatic sediments: implications for benthic nutrient recycling. Estuaries 14(2): $167-1.74$

Shugart, H. H., O'Neill, R. V. (1979). Systems ecology. Benchmark papers in ecology 9. Dowder, Hutchinson \& Ross, Inc., Stronsburg

Tiedje, J. M., Sunking, S., Groffman, P. M. (1989). Perspectives on measurements of denitrification in the field including recommended protocols for acetylene based methods. Plant Soil 115: 261-284

Ulanowicz, R. E. (1986). Growth and development: ecosystem phenomenology. Springer-Verlag, New York

Ulanowicz, R. E., Kemp (1979). Toward canonical trophic aggregations. Am. Nat. 114: 871-883

Vidal, M. (1990). Estudios sobre la dinamica de nutrientes en sistemas estuaricos: flujos sedimento-agua de nutrientes y oxígeno. Ph.D. thesis, Universitat de Barcelona

Wulff, F., Ulanowicz, P. M. (1989). The comparative anatomy of the Baltic Sea and the Chesapeake Bay ecosystems. In: Mann, K. H., Field, J. G., Wulff, F. (eds.) Network analysis in marine ecology: methods and applications. SpringerVerlag, Heidelberg, p. 232-258

Manuscript first received: August 20, 1992

Revised version accepted: January 12, 1994 